\title{
Inequality and Economic Growth: An Analysis of 8-Panels
}

\author{
Khadijah A. Idowu ${ }^{1} \&$ Yusuf Babatunde Adeneye 2* $^{*}$ \\ ${ }^{1}$ Department of Accounting, Lagos State University, Nigeria \\ ${ }^{2}$ Finance and Economics Department, University of Leicester, UK \\ *Yusuf Bababtunde Adeneye, E-mail: Yba2@le.ac.uk
}

Received: August 22, 2016

Accepted: September 5, 2016

Online Published: March 31, 2017

doi:10.22158/jepf.v3n2p173

URL: http://dx.doi.org/10.22158/jepf.v3n2p173

\begin{abstract}
Purpose: This paper investigates the effects of inequality on economic growth in the world using continental approach.

Design/methodology: Gini Coefficient and Gross Domestic Products (GDP) per capita were used to measure inequality and economic growth respectively. The study conducted a panel data analysis of the relationship between inequality and economic growth. The data span from 1991-2015. Five countries were selected each from seven continents and were also pooled together to constitute a single panel for 35 countries, thus establishing 8 panels. The Hausman test was conducted to determine whether a random or fixed effect model best fit pooled countries analysis or not.

Findings: Findings revealed that for the developing countries, high income inequality retards economic growth while for the developed countries such as Europe countries; the situation seems to be different. European countries as revealed in the findings showed that developed countries have benefited from inequality which has significantly and positively affected their economic growth. The results for Panel II (Asia countries) and Panel III (Europe countries) are in line with the study of Forbes (2000) and Li and Zou (1998) that documented that inequality boosts economic growth. Importantly, we found that inequality positively affects economic growth for Panels/Continents with fixed effect model while inequality negatively affects economic growth for Panels/Continents with random effect model.

Research Limitation: The study did not control for each continent differences. For African countries, weak institutional settings and environment is a key factor contributing to high inequality.

Originality: The paper was able to know the specific effect of inequality on economic growth in each continent in the World. This documents continents that have benefited from inequality and those that inequality has greatly affected their economies negatively.
\end{abstract}

\section{Keywords}

inequality, economic growth, cross-continents 


\section{Introduction}

There have been inconclusive evidences on the nexus between inequality and economic growth. The theoretical submission of Kaldor (1960) and Kalecki (1971) in their post-Keynesian paper stated that favourable economic growth exists in the presence of inequality. The authors argued that the transfer of workers' savings to capitalists raises the aggregate savings of the economy which in turn contributes positive to the growth of the economy. Despite the high number of literature on the nexus between inequality and economic growth (Angeles-Castro, 2006; Barro, 2000; Cingano, 2014; Galbraith, 2012; Heyse, 2006; Jihène \& Ghazi, 2013; Tabassum \& Majeed, 2008; Wahiba \& El Weriemmi, 2014), there have been inconsistencies in empirical findings in developed, emerging and developing countries. The discussion paper of Bagchi and Svejnar (2015) suggests that wealth inequality, initial poverty and income inequality do not affect economic growth. The authors noted that inequality reduces economic growth only when wealth inequality is politically connected. This submission of Bagchi and Svejnar (2015) cannot be generalized given the decade of research in literature on inequality and its effects on economic growth.

The differences in empirical evidences can be attributed to measures of inequality, data analyses and the methodology employed. Alesina and Rodrik (1994) and Rodriguez (2000) found little benefit of inequality on economic growth when income inequality is measured using Gini Index. Pineda and Rodriguez (1999) found inequality negatively affecting economic growth when a country has high capital shares indicating low investments in human capital. Benabou (1996) submits that of the 13 studies in his paper, ten were found to establish significant negative relationship between inequality and economic growth; two were also found to be positive but insignificant while one was found to establish no relationship. These negative relationships are inconsistent with the studies of Persson and Tabellini (1994), Forbes (1997), Li and Zou (1998) and Barro (1999). The use of AR/PT regression, country-specific fixed effects, measures of share of median voter in GDP, Seemingly unrelated regressions technique, short run variations and short or large moving averages have resulted in inequality having positive effect on economic growth except with the Barro and Sala-I-Martin (1995) regression model that establishes no linear relationship between inequality and economic growth. In addition, Rodriguez (2000) submits that when five years averages are used, inequality affect economic growth in the short run while long run relationship is established when ten-year averages are used as observation. The inconclusive evidence was also based on single country, cross-country analysis and institutional analysis (Barro, 2000; Iradian, 2005; De-Dominicis et al., 2006; Castells \& Royuela, 2012; Ncube et al., 2014; Hunter et al., 2016). The cross-continental analysis offers an opportunity to gain new evidence. Distinct from cross-country analysis, cross-continental analysis features high level of gender inequality, poverty rate and income inequality in Africa (Habimana, 2014; Go et al., 2007), developing Asia has priority for economic growth over inequality thus seeing growth has cause of inequality (Lee, H., Lee, M., \& Park, 2012). In addition, Latin America has the highest income inequality among continents. This has resulted in economic instability, recurrent crisis and 
sociopolitical instability (Gasparini \& Lustig, 2011; Delbianco, Dabus, \& Caraballo, 2014). Lastly in Europe, inequality is attributed to unequal endowment, differences in economic structures, housing bubble, global turndown all due to the adoption of euro in the early nineties of the Great Recession (Petrakos, 2009; Ramos \& Royuela, 2014).

Using eight panels' data analyses, each representing Africa (Panel I), Asia (Panel II), Europe (Panel III), Less Developed (Panel IV), North America (Panel V), South America (Panel VI), Oceania (Panel VII) and Selected Countries (Panel VIII), over the periods 1991-2015, the objectives were to examine (1) the extent to which Gini index affect economic growth across continents, (2) to establish whether the same result is evidence across the continents, and (3) which continents benefit from the presence of inequality.

This study contributes in three ways. Firstly, the study did a panel analysis of all the continents, thus making this study a continent analysis. We selected five countries from each continent using the level of economic development represented with gross domestic products. We represented each continent as a mini panel and combined all the panels together as a combined panel. This was to establish the influence of inequality on economic growth continentally and as a geographical data when all the continents are pooled together as single panel. Findings thus differ across continents and changed in combined panel data. Secondly, this paper was able to establish the continents that benefitted most from inequality and those that see inequality negatively affect economic growth. Finally, we adopted the use of Gini Index in all continental analyses to ensure smooth comparison and to reduce the criticism of Gini index as a measure of inequality in already established literatures.

This paper is structured as follows: Section 1 introduces the differences in literature on inequality and the contribution of this paper. Section 2 presents the theoretical foundation of this study. Section three presents the research methods of this paper. Section four presents the analysis and results and section five discusses and concludes this paper.

\section{Theoretical Foundation and Theories of Inequality}

Several theories have been used to capture the measures of inequality. Although while some authors have used different theories, it can be argued that the use of these theories is dependent on the nature or forms of inequality. For example, Bakare (2012) has adopted the Gini Coefficient and the Lorenz curve to explain income inequality, Han et al. (2012) used the biosocial, psycho-social, political and social theories to explain the social context of inequality.

\subsection{Lorenz Curve}

Bakare (2012) noted that the use of Lorenz curve is geared toward measuring differences in personal income. The author noted that the curve has both horizontal and vertical axes where both cumulative percentages of income recipients and the percentage of total income received are plotted. Bakare (2012) noted that a diagonal line joins the two axes and any point on it connotes that a certain income received is proportionally related to the percentage of income recipients. Importantly, Bakare (2012) stated that 
the more the Lorenz curve differs from the diagonal line, the greater the level of income inequality. Higher income inequality would be present when one individual receives a larger percentage of the national income.

\subsection{Gini Coefficients}

The use of Gini Coefficient (GC) as a measure of income inequality can be traced to Gini (1912), an Italian man who formulated the Gini Coefficient. Bakare (2012) noted that the GC is derived from the Lorenz curve stating that it is a ratio of area difference between the Lorenz curve and the diagonal divided by the total area of the curve where it lies. Bakare (2012) noted that the coefficient range from 0 to 1 . The author noted that as the coefficient before higher and stronger, so also does the level of inequality increases while it decreases as the GC tends to zero. This indicates that for countries with high income inequality, the Gini Coefficient is between 0.5 and 0.7 while for countries with relatively low Gini Coefficient, the value is between 0.2 and 0.4. However, irrespective of the value attached to it, it shows that the higher the Gini Coefficient, the higher the presence of income inequality while the lower it is, the higher the presence of equality distribution.

Although, aside the Lorenz and the Gini Coefficient, Kefi and Zouhaier (2012) identified that other measures have been used. These measures are; GDP per capita in purchasing power parity (a measure on international inequality), Human Development Index (HDI) (Morris, 1979) and the quality life index (Hicks \& Streeten, 1979). Mbaku (1997) however argued that the human development index and the quality life index are better than the GDP per capita measure staying that the variation in income inequality can best be explained by these two indicators. Mbaku (1997) studied the nexus between income inequality and economic growth using the human development index and the quality life index. Contrarily, Galor and Moav (2004) have rightly argued the importance of the human and physical capital accumulation in relation to inequality. Galor and Moav (2004) argued that in a situation whether the propensity to save increases proportionally with income, then inequality is right for physical capital accumulation while noting that equality is conducive for human capital accumulation. Thus, according to Galor and Moav (2004), Human Development Index (HDI) may not capture inequality but can be captured by physical capital index. Due to the wide adoption of Gini Coefficient as a measure of inequality, this study theoretical foundation was built around the theory. The theoretical model of this study is presented below. The model presented the theory that explains the relationship between inequality and economic growth.

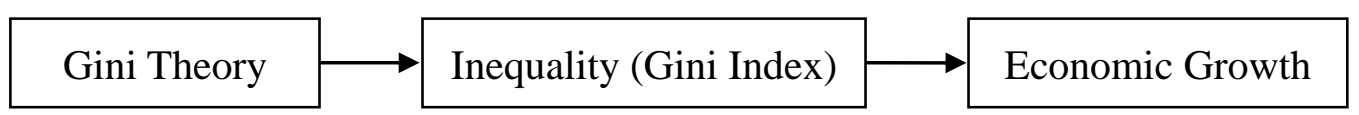

Figure 1. Theoretical Model of the Study

\subsection{Relationship between Inequality and Economic Growth}

Kefi and Zouhaier (2012) examined the effect of inequality on economic growth. GDP per capita was 
used to capture economic growth while GINI was used to measure inequality. Corruption and political instability were controlled for in their study. Using GMM estimation technique and dynamic panel model of eight developing countries for period 2002 to 2009, findings revealed that there is a negative relationship between inequality and economic growth. The authors also revealed that the nexus between inequality and economic growth is bi-directional both demand-following and supply-leading. The study suffers from some deficiencies. Kefi and Zouhaier (2012) failed to analyse the effects of inequality on the thresholds level of economic development. In addition, few countries (sample size) were considered. Alesina and Rodrik (1994), Persson and Tabellini (1994) Alesina and Perotti (1996), Perotti (1996) and Deininger and Squire (1998) found a negative relationship between inequality and economic growth using the Ordinary Least Square (OLS) method for some countries for period 1960-1980s. Contrarily, Forbes (2000) and Li and Zou (1998) revealed a positive relationship between inequality and economic growth using the fixed effect model. In their studies, when the Gini Coefficient is increased by 1 Standard Deviation (SD), then annual economic growth rate (GDP growth rate) increases by $1 / 2 \%$ in the case of $\mathrm{Li}$ and Zou (1998) while when the Gini Coefficient is increased by $1 \mathrm{SD}$, then annual growth will increase by $1 / 3 \%$ as incase of Forbes (2000). Barro (2000) study on inequality and economic growth seems to be different from previous authors. Barro (2000) revealed that inequality does not statistically affect economic growth when the countries are cross examined together. However, when they are divided into both rich and poor economies, there was statistical positive relationship between inequality and economic growth for rich countries while statistically negative for the poor countries. It can therefore be concluded that the degree or pattern of relationship between inequality and economic growth may be due to the nature of statistical data, estimation techniques, capital endowment and countries included in the sample.

\subsection{Inequality and Social Cohesion, Health and Well Being}

Much literature has documented the link between inequality and social cohesion (Alesina \& Glaeser, 2004; Dorling, 2010; Mueller, 1997; Wilkinson \& Pickett, 2010). Different results have also been established. Wilkinson and Pickett (2010) revealed that there is a negative relationship between inequality, public health and social cohesion. Wilkinson and Pickett (2010) noted that the higher the level of income inequality, the lower the public health and well being which in turns also lowers the social cohesion in a country. Based on this, Green et al. (2006) stated that the level of educational equality is any nation is linked to the level of social cohesion, i.e., the higher the social cohesion, the higher the educational equality. This result according to Han et al. (2012) noted that when the income inequality of a country is reduced to an extent that the society is now an income-equality one, then there will be evidenced of higher social and political trust and lower violent crime in the society. Wilkinson and Pickett (2010) noted that that there is a negative relationship between income inequality and economic growth. The authors stated that in most advanced capitalist economies, higher income inequality determines a lower social cohesion and invariably affect the heath status of the populace. According to Coburn (2000), he noted that the social context of inequality and the neo-liberal 
assumptions documented that a link between neo-liberal political doctrines, income inequality and social cohesion. Coburn argued that the political doctrines have along had a negative effect on the welfares of the state noting that this will affect the health status of the state and of course serves as an underlying cause for negative or lowered social cohesion. Coburn (2000) concluded that as globalization affects the doctrines of the market capitalism, social cohesion and heath status will decline drastically. He advised for identification of causes of inequality such as globalization rather than the effects of inequality on economic growth and development. While Coburn may have seen inequality as negatively lowering social cohesion, Easterly et al. (2006) evidenced that social cohesion is an endogenous determinant of institutional quality which in turns determine economic growth.

Based on this review, we hypothesized that:

Ho1: Inequality positively affects economic growth for a fixed effect model, and

Ho2: Inequality negatively affects economic growth for a random effect model.

\section{Methodology}

The study conducted a panel data analysis of the relationship between inequality and economic growth. Inequality was measured using Gini Coefficient as identified in previous studies ( $\mathrm{Li} \& \mathrm{Zou}, 1998$; Forbes, 2000; Rodriguez, 2000; Bakare, 2012; Kefi \& Zouhaier, 2012). Economic growth was measured using Gross Domestic Products (GDP) per capita. The data span from 1991-2015. The data was gotten from the World Bank Indicator database. Five countries were selected each from different continents and were also pulled together to constitute a single panel for 35 countries. The Table 1 shows the countries selected from each continent. The countries were selected on the bases of 5 most ranked highest GDP countries in Africa as noted by the World Bank GDP ranking.

Table 1. Countries Selected from Each Continent

\begin{tabular}{|c|c|c|c|c|c|c|c|}
\hline $\begin{array}{l}\text { Africa } \\
\text { (Panel I) }\end{array}$ & $\begin{array}{l}\text { Asia } \\
\text { (Panel II) }\end{array}$ & $\begin{array}{l}\text { Europe } \\
\text { (Panel III) }\end{array}$ & $\begin{array}{l}\text { Less } \\
\text { Developed } \\
\text { (Panel IV) } \\
\end{array}$ & $\begin{array}{l}\text { North } \\
\text { America } \\
(\text { Panel V) }\end{array}$ & $\begin{array}{l}\text { South } \\
\text { America } \\
(\text { Panel VI) }\end{array}$ & $\begin{array}{l}\text { Oceania } \\
\text { (Panel VII) }\end{array}$ & $\begin{array}{l}\text { Selected } \\
\text { Countries } \\
\text { (Panel VIII) }\end{array}$ \\
\hline Nigeria & China & Germany & Angola & $\begin{array}{l}\text { United } \\
\text { States }\end{array}$ & Argentina & Australia & $\begin{array}{l}\text { A combination } \\
\text { of Panels I-VII. }\end{array}$ \\
\hline $\begin{array}{l}\text { South } \\
\text { Africa }\end{array}$ & Japan & $\begin{array}{l}\text { United } \\
\text { Kingdom }\end{array}$ & $\begin{array}{l}\text { Solomon } \\
\text { Islands }\end{array}$ & Canada & Chile & Micronesia & $\begin{array}{l}\text { This makes } 35 \\
\text { countries in all. }\end{array}$ \\
\hline Egypt & India & France & Haiti & Mexico & Uruguay & Fiji & \\
\hline Algeria & Indonesia & Italy & Benin & $\begin{array}{l}\text { Dominican } \\
\text { Republic }\end{array}$ & Venezuela & Kiribati & \\
\hline Morocco & Iran & Russia & Madagascar & Guatemala & Brazil & Samao & \\
\hline
\end{tabular}

Source: World Bank GDP Ranking, 2014, 2015.

Data were gotten on Gini Coefficient and GDP per capita and thereafter arranged in a panel data form. Quantitative data analysis was conducted. Unit root (using summary of ADF, PPF, LLC) was conducted to establish the stationary of the data sets (This is one of the requirements in the use of OLS estimation). 
Multicollinearity was also done using correlation analysis as any figure above 0.8 means there is evidence of Multicollinearity. Descriptive statistics were also done to explain the nature of the data sets of the variables. Eight panels were established as noted in the table above. The eighth panel (Panel VIII) is the panel that joins all the countries together. The panel data analysis was based on fixed effect and random effect models. We used the Hausman test to verify the appropriate effect model for each panel/continent.

\section{Analysis and Results}

Some preliminary tests were done and panel data analysis including diagnostics tests was presented.

Table 2. Unit Root Test

\begin{tabular}{|c|c|c|c|c|c|c|c|c|}
\hline & $\begin{array}{l}\text { Africa } \\
\text { (Panel I) }\end{array}$ & $\begin{array}{l}\text { Asia } \\
\text { (Panel II) }\end{array}$ & $\begin{array}{l}\text { Europe } \\
\text { (Panel III) }\end{array}$ & $\begin{array}{l}\text { Less } \\
\text { Developed } \\
\text { (Panel IV) }\end{array}$ & $\begin{array}{l}\text { North } \\
\text { America } \\
(\text { Panel V) }\end{array}$ & $\begin{array}{l}\text { South } \\
\text { America } \\
\text { (Panel VI) }\end{array}$ & $\begin{array}{l}\text { Oceania } \\
\text { (Panel } \\
\text { VII) }\end{array}$ & $\begin{array}{l}\text { Selected } \\
\text { Countries } \\
\text { (Panel VIII) }\end{array}$ \\
\hline GDP & $\mathrm{I}(1)^{*}$ & $\mathrm{I}(1)^{*}$ & I (1)* & $\mathrm{I}(1)^{*}$ & $\mathrm{I}(1)^{*}$ & $\mathrm{I}(1)^{*}$ & $\mathrm{I}(1)^{*}$ & $\mathrm{I}(1)^{*}$ \\
\hline GINI & & & $\mathrm{I}(1)^{*}$ & & $\mathrm{I}(1)^{*}$ & $\mathrm{I}(2)^{* *}$ & $\mathrm{I}(2)^{* * *}$ & $\mathrm{I}(1)^{*}$ \\
\hline
\end{tabular}

* Significant at $1 \%, 5 \%$ and $10 \%$ level of significant.

* Significant at ADF, PPF and LLC.

** Gini was stationary for South America (Panel VI) at second difference.

Some panels did not show unit root for GINI due to the fact that the number of identified data for these panels were few. To address this situation, we assumed that GINI was stationary at its first difference for panels/continents which unit roots were not displaced during the statistical tests. We based our argument on the fact that the GINI results of other Panels that were displaced were stationary at their first difference. From Table 2, it shows that GDP is stationary at first difference. It was not stationary for all the panels at levels so a first difference stationary was conducted.

Table 3. Descriptive Statistics

\begin{tabular}{|c|c|c|c|c|c|c|c|c|c|}
\hline & & $\begin{array}{l}\text { Africa } \\
\text { (Panel I) }\end{array}$ & $\begin{array}{l}\text { Asia } \\
\text { (Panel II) }\end{array}$ & $\begin{array}{l}\text { Europe } \\
\text { (Panel } \\
\text { III) }\end{array}$ & $\begin{array}{l}\text { Less } \\
\text { Developed } \\
(\text { Panel IV) }\end{array}$ & $\begin{array}{l}\text { North } \\
\text { America } \\
\text { (Panel V) }\end{array}$ & $\begin{array}{l}\text { South } \\
\text { America } \\
\text { (Panel VI) }\end{array}$ & $\begin{array}{l}\text { Oceania } \\
\text { (Panel } \\
\text { VII) }\end{array}$ & $\begin{array}{l}\text { Selected } \\
\text { Countries } \\
\text { (Panel VIII) }\end{array}$ \\
\hline \multirow[t]{2}{*}{ Mean } & GDP & 2363.577 & 8922.544 & 25890.28 & 871.6081 & 16568.16 & 7014.172 & 8220.814 & 9981.368 \\
\hline & GINI & 49.20533 & 36.44652 & 35.98280 & 45.64308 & 45.91627 & 50.01914 & 39.63200 & 44.27346 \\
\hline \multirow[t]{2}{*}{ Jarque-Bera } & GDP & 32.67796 & 44.24505 & 4.702073 & 533.1806 & 16.78423 & 13.82425 & 324.3226 & 459.1547 \\
\hline & GINI & 1.415807 & 1.768846 & 5.818450 & 2.189238 & 5.947335 & 3.500982 & 8.999431 & 8.083346 \\
\hline \multirow[t]{2}{*}{ Probability } & GDP & 0.000000 & 0.000000 & 0.095270 & 0.000000 & 0.000227 & 0.000996 & 0.000000 & 0.000000 \\
\hline & GINI & 0.492676 & 0.412952 & 0.054518 & 0.334667 & 0.051116 & 0.173689 & 0.011112 & 0.017568 \\
\hline
\end{tabular}

Source: EViews Output, 2016.

Table 3 shows the descriptive statistics of GDP and Inequality (as measured using GINI) for Panels I to Panel VIII. From the descriptive table, Europe has the highest mean values for GDP with $\$ 25,890.28 \mathrm{~m}$ 
followed by North America with mean value of $\$ 16,568.16 \mathrm{~m}$. Africa (Panel I) is the second to the last in the mean value ranking with mean value of $\$ 2,363.57 \mathrm{~m}$ while the less developed (Panel IV) countries have the lowest mean value of $\$ 871.6081 \mathrm{~m}$. Based on the results, it shows that in term of economic growth and development, the ranking of GDP continents is; Europe (1st), North America (2nd), Asia (3rd), Oceania (4th), South America (5th), Africa (6th) and Less developed (7th).

Based on the ranking of inequality, South America is the 1st (having a mean value of GINI of 50.01914), Africa is 2nd (mean value is 49.20533), North America is 3rd (mean value is 45.91627), Less developed is 4 th (mean value is 45.64308), Oceania is 5th (mean value is 45.64308), Asia is 6th (mean value is 36.44652) and Europe is 7th (mean value is 35.9828). This connotes that Europe has the least inequality in the world. Birdsall and Londono (1997) buttressed that there is high level of inequality and slow growth in Latin America countries while low level of inequality in Asian countries with fast growth. This can be seen in the table that the mean value of Asia countries for GINI (as a measure of inequality) is 36.4465 lower than that of both North and South America countries with respective GINI mean values of 45.9162 and 50.01915. In fact, in this paper, South America countries are ranked as the first in inequality.

Normality test can be conducted using Jargue-Bera test. This according to Maxwell and Peter (2016) stated that Jargue-Bera is premised on establishing the normally distribution of the measured variables. Brooks (2008) noted that Jargue-Bera significance is dependent on the p-value being less than 0.05 (5\% level of significance). Based on the value of JB in the table above, it shows that the JB probabilities of the Panels I to VIII for GDP is normally distributed. Although, based on the unit root test of the GDP of the Panels were all significant at first difference. On the GINI (a measure of inequality), none of the variables were normal at $1 \%, 5 \%$ and $10 \%$ level of significance. These GNIs were made normally distributed at first difference (Kindly see the unit root table). At this point, the variables; GDP and GINI are now normally distributed and made the use of regression analysis suitable for the study.

Table 4. Correlation between Inequality and Economic Growth

\begin{tabular}{lllllllll}
\hline & $\begin{array}{l}\text { Africa } \\
\text { (Panel I) }\end{array}$ & $\begin{array}{l}\text { Asia } \\
\text { (Panel } \\
\text { II) }\end{array}$ & $\begin{array}{l}\text { Europe } \\
\text { (Panel } \\
\text { III) }\end{array}$ & $\begin{array}{l}\text { Less } \\
\text { Developed } \\
\text { (Panel IV) }\end{array}$ & $\begin{array}{l}\text { North } \\
\text { America } \\
\text { (Panel V) }\end{array}$ & $\begin{array}{l}\text { South } \\
\text { America } \\
\text { (Panel VI) }\end{array}$ & $\begin{array}{l}\text { Oceania } \\
\text { (Panel }\end{array}$ & $\begin{array}{l}\text { Selected } \\
\text { Countries } \\
\text { (Panel VIII) }\end{array}$ \\
\hline $\begin{array}{l}\text { R Square } \\
\text { (GDP \& GINI) }\end{array}$ & 0.7547 & -0.0957 & -0.8237 & -0.0260 & -0.7538 & -0.4271 & -0.5061 & -0.5453 \\
\hline
\end{tabular}

Source: EViews Output, 2016.

Table 4 shows the correlation analysis of the relationship between Gross Domestic Product (GDP) and Gini Coefficient. Based on the table below, all the panel models showed negative relationship between GDP and inequality except for Panel 1 (Africa) which revealed a strong positive between inequality and economic growth $(\mathrm{R}=0.7547)$. This finding means that inequality in Africa has a positive effect on the economic growth of Africa countries, thus, the higher the inequality, the stronger the GDP. The 
result for Panel I contradicts the submission of Barro (2000) that inequality retards economic growth in poor countries and encourage growth in rich ones.

Panel III (Europe) shows a strong negative correlation between inequality and economic growth $(\mathrm{R}=$ -0.8237). This means the higher the inequality in European countries, the lower the Gross Domestic Product (economic growth). In addition, the adverse effects of inequality on Europe $(\mathrm{R}=-0.8237)$, North America $(R=-0.7538)$, Oceania $(R=-0.5061)$ is stronger on the economic growth of countries in these continents. However, there is a weak correlation between inequality and economic growth $(\mathrm{R}=$ $-0.4271)$.

Table 5. Correlated Random Effects-Hausman

\begin{tabular}{|c|c|c|c|c|c|c|c|c|}
\hline & $\begin{array}{l}\text { Africa } \\
\text { (Panel I) }\end{array}$ & $\begin{array}{l}\text { Asia } \\
\text { (Panel II) }\end{array}$ & $\begin{array}{l}\text { Europe } \\
\text { (Panel III) }\end{array}$ & $\begin{array}{l}\text { Less } \\
\text { Developed } \\
\text { (Panel IV) }\end{array}$ & $\begin{array}{l}\text { North } \\
\text { America } \\
\text { (Panel V) }\end{array}$ & $\begin{array}{l}\text { South } \\
\text { America } \\
\text { (Panel VI) }\end{array}$ & $\begin{array}{l}\text { Oceania } \\
\text { (Panel } \\
\text { VII) }\end{array}$ & $\begin{array}{l}\text { Selected } \\
\text { Countries } \\
\text { (Panel VIII) }\end{array}$ \\
\hline $\begin{array}{l}\text { Chi-Sq } \\
\text { Statistics }\end{array}$ & 0.001890 & 1.330072 & 25.731064 & 2.286394 & 8.359546 & 6.531013 & 2.502760 & 7.434866 \\
\hline Prob. & 0.9653 & 0.2488 & 0.0000 & 0.1305 & 0.0038 & 0.0106 & 0.1136 & 0.0064 \\
\hline Panel & Random & Random & Fixed & Random & Fixed & Random & Random & Random \\
\hline Model & Effect & Effect & Effect & Effect & Effect & Effect & Effect & Effect \\
\hline
\end{tabular}

Source: EView Output, 2016.

Table 5 shows the Hausman Test that indicates whether a random or fixed effect would be appropriate. If the probability of the chi-square statistics is less than $5 \%$, then the fixed effect is appropriate, otherwise the random effect is appropriate. Based on the results in the table, Panel III, V, VI and VIII follow the fixed effects while Panels I, II, IV and VII follow the random effects.

Table 6. Equation Table: Dependent Variable (Real GDP)

\begin{tabular}{llllll}
\hline & & Coefficient & Standard Error & T & \\
\hline Panel I & Constant & 94.58 & 52.43 & 1.803 & Prob(F-statistic) $=0.938$ \\
& GINI & -1.3685 & 18.068 & -0.075 & R Square $=0.0094$ \\
Panel II & Constant & 80.188 & 286.11 & 0.2802 & Prob(F-statistic) $=0.891$ \\
& GINI & 29.322 & 218.97 & 0.1339 & R Square $=0.04$ \\
Panel III & Constant & 973.03 & 451.20 & 2.15 & Prob(F-statistic) $=0.5107$ \\
& GINI & 179.83 & 278.79 & 0.64 & R Square $=0.0106$ \\
Panel V & Constant & 72.70 & 51.98 & 1.398 & Prob(F-statistic) $=0.15$ \\
& GINI & -18.720 & 13.15 & -1.40 & R Square $=0.029$ \\
Panel VI & Constant & 141.050 & 88.186 & 1.59 & Prob(F-statistic) $=0.003$ \\
& GINI & -180.235 & 58.686 & -3.07 & R Square $=0.6187$ \\
Panel VII & Constant & 388.33 & 174.75 & 2.222 & Prob(F-statistic) $=0.0127$ \\
& GINI & -296.38 & 114.81 & -2.581 & R-Squared $=0.1329$ \\
& Constant & 1563.53 & 1886.47 & 0.8288 & Prob(F-statistic) $=0.510$ \\
& GINI & -29.132 & 45.223 & -0.6441 & R Square $=0.008$ \\
& Constant & -3969.38 & 2969.35 & -1.366 & Prob(F-statistic) $=0.168$ \\
& GINI & 100.269 & 74.069 & 1.353 & R-Squared $=0.0551$ \\
\hline
\end{tabular}

Source: EView Output, 2016. 
Based on the coefficients in Table 6, it can be seen that Panels V and VI are significant given that their prob. (F-Statistics) is 0.000 less than $5 \%$ level of significance. This indicates that inequality significantly affect economic growth in North America and South America. Table 6 also revealed that inequality has negative relationship with economic growth for Panels I (Africa), Panel IV (Less Developed), Panel V (North America), Panel VI (South America) and Panel VII (Oceania). This implies that an incremental change in inequality will result in decremental change in economic growth in these Panels/Continents. That is, a reduction in inequality will result in an increase in real GPD of countries in Africa, Less Developed, North America, South America and Oceania. Geda and Shimeless (2006) support that inequality negatively affects economic growth in Africa which is characterized by external dominance. According to Geda and Shimeless (2006), Africa economy is characterized by weak productive base, foreign and trade exchange nature of the economy, predominant subsistence and level of its finance and international trade openness. All of these factors have conspired in making Africa economy vulnerable to exogenous shocks and the reason for Africa slow growth. In the opinion of Leibbrandt et al. (2010), he stated that in South Africa, many unemployed individuals live in households where no one is employed and earnings inequality among the employed has also decline the financing supports for the unemployed to start businesses. This situation is thus responsible for inequality in the region.

Table 6 also reveals that there is a positive relationship between inequality and economic growth in Panels II (Asia), Panel III (Europe) and Panel VIII (Selected Countries). This indicates that Europe and Asia countries benefit from inequality. This implies that the higher the inequality in Europe and Asia, the higher the economic growth. A unit change in inequality will bring about 29.32 units contribution to economic growth in Asia while it will bring about 179.83 units contribution to economic growth in Europe. European Union (2010) document that the nature of economic growth in Europe in recent decades enhances inequality with social and economic evils on the high side.

Dabla-Norris et al. (2015) argued that inequality is important for the sustainability of economic growth. The authors further explained that the income distribution or share among bottom $20 \%$ among the poor is associated with increased economic growth in the long term while top $20 \%$ income share among the rich is associated with increased inequality in the short term.

The differences in equality between countries that have benefited from (in Europe) and do not benefit from (Africa, Less Developed, North and South America) inequality may be due to technological process, no one-size-fits-all approach in tackling inequality and designing policies that focus on the middle and poor class. Contrarily, Barro (2000) also argued that even developing countries can benefit form inequality. According to Barro (2000), he stated that authorizing or permitting few individuals to accurate income and resourced needed to start business and get quality education developing countries can foster economic growth. Dabla-Norris et al. (2015) also put forward that inequality that provides the environment for individuals to compete, save, excel and invest can change the social well being of the people and thus enhance economic growth. Lazear and Rosen (1981) buttressed that human capital 
accumulation is dependent on people returning to education and labour earnings differentiation. Through this human capital accumulation, economic growth can be enhanced despite the high income inequality in place (Lazear \& Rosen, 1981). The positive relationship between inequality and economic growth also documented in Panel II (Asia) can also be attributed to innovation and entrepreneurship which are required to foster economic growth. We therefore conclude that inequality positively affects economic growth for Panels/Continents with fixed effect model while inequality negatively affects economic growth for Panels/Continents with random effect model.

\subsection{Diagnostic Test}

We used the normality graph test to establish the validity of each panel. We conducted a residual diagnostic test and confirm that the profitability of Jarque Bera of all the Panels were significant at $1 \%$. Equally, the mean values of the Normality graph conducted tend towards zero. This confirms that the fixed and random effects models for the panels established in Table 6 were valid and reliable. The graphs were 8 in number due to eight panels and were not presented here due to space that the graph will take.

\section{Discussions and Conclusion}

Findings revealed that for the developing countries, high income inequality retards economic growth while for the developed countries such as Europe countries; the situation seems to be different. European countries as revealed in the findings showed that developed countries have benefited from inequality which has significantly and positively affected their economic growth. This paper suffered from few limitations. Despite trying to close the inconsistencies results in the nexus between inequality and economic growth, this paper only adopted the Gini Index as a measure of inequality. Robust analysis would involve the use of Gini Index (GI), Human Development Index (HDI), Quality Life Index (QLI), Capital Shares (CS), Purchasing Power Parity (PPP), Endowment (END), Global Turndown (GT), Housing Bubble (HB) and Economic Structures (ES). The implication in the use of these measures as explanatory variables would help to establish what measure(s) of inequality greatly influence economic growth. We were able to close the gap in literature when Gini Index is used as measure of inequality. Equally, we cannot establish what really affect economic growth among continents; whether it is HDI, International Inequality (PPP), Housing Bubble (HB) or other measures of inequality. This study only concentrated on Gini Index. This study also suffers from the use of control variables as only inequality cannot determine or explain economic growth. Financial development, financial deepening and economic productivity are greatly important in explaining economic growth. We deliberately did not include these control variables in order to establish the true influence of inequality on economic growth. Statistically, the use of control variables can influence the coefficient patterns of explanatory variables in a study and thus may not present the true effects of the explanatory variable(s) on the dependent variable. Ilvento $(2011$, p. 3) stated that controlling for other variables in the model will likely increase and decrease the strength of the relationship between an 
independent variable (Inequality) and the dependent variable (economic growth), reverse the sign (e.g., from positive to negative) and leave it relatively unchanged. Thus, the study did not control for important variables like institutional quality, corruption, public health, political trust, political instability and educational equality. In addition, the sample size used in this study for each continent may represent $9 \%-15 \%$ (5 countries per continent) of the total countries in the continent and may not be an adequate representation. Although, our use of gross domestic products may imply that the GDP of the five selected countries can account for about $67 \%$ of the total GDP for the continent. We recommend that governments of developing countries or countries should develop their financial markets and enhance productivity through human capital development. The disadvantages of inequality accruing to developing countries are indications of high level corruption and the control of the economy by a select few. Financial inclusion should also be harnessed. Further studies should examine the determinants of inequality using many variables for a long period say 40 years and above. The implication of this is to get good precision of variables. We suggested a longer period of study because for continents/panels that their GINI results did not displayed during statistical tests were all appropriate using random effect model while for those panels that their GINI results displayed were all appropriate at fixed effect model. A major limitation in this study is the unavailability of data for some periods under study for GINI across panels.

\section{References}

Alesina, A., \& Glaeser, E. L. (2004). Fighting poverty in the US and Europe: A world of difference. Oxford: Oxford University Press. https://dx.doi.org/10.1093/0199267669.001.0001

Alesina, A., \& Perotti, R. (1996). Income distribution, political instability, and investment. European Economic Review, 40(6), 1203-1228. https://doi.org/10.1016/0014-2921(95)00030-5

Alesina, A., \& Rodrik, D. (1994). Distributive politics and economic growth. The Quarterly Journal of Economics, 109(2), 465-490. https://doi.org/10.2307/2118470

Angeles-Castro, G. (2006). The relationship between economic growth and inequality: Evidence from the age of market liberalism. No 2, Proceedings of the German Development Economics Conference, Berlin 2006, Verein für Socialpolitik, Research Committee Development Economics.

Bagchi, S., \& Svejnar, J. (2015). Does wealth inequality matter for growth? The effect of billionaire wealth, income distribution, and poverty. Journal of Comparative Economics, 43(3), 505-530. https://doi.org/10.1016/j.jce.2015.04.002

Bakare, A. S. (2012). Measuring the income inequality in Nigeria: The Lorenz Curve and Gini co-efficient approach. American Journal of Economics, 2(1), 47-52. https://dx.doi.org/10.5923/j.economics.20120201.06

Barro, R. J. (1999). Inequality, growth and investment (NBER Working Paper).

Barro, R. J. (2000). Inequality and growth in a panel of countries. Journal of Economic Growth, 5(1), 5-32. https://doi.org/10.1023/A:1009850119329 
Barro, R., \& Sala-i-Martin, X. (1995). Economic growth. New York: McGraw Hill.

Benabou, R. (1996). Inequality and growth. In NBER Macroeconomics Annual 1996 (Vol. 11, pp. 11-92). MIT Press.

Birdsall, N., \& Londono, J. L. (1997). Asset inequality does matter: Lessons from Latin America (OECD Working Paper). Inter America development Bank, mars.

Brooks, C. (2008). Introductory econometrics for finance. Cambridge: University Press.

Castells, D., \& Royuela, V. (2012, October). Agglomeration, Inequality and Economic Growth: Cross-section and panel data analysis. In ERSA conference papers (p. 492). European Regional Science Association.

Cingano, F. (2014). Trends in income inequality and its impact on economic growth (OECD Social, Employment and Migration Working Papers).

Coburn, D. (2000). Income inequality, social cohesion and the health status of populations: The role of $\begin{array}{lllll}\text { neo-liberalism. Social Science \& } \quad \text { Medicine, } & \text { 5l(1), 135-146. }\end{array}$ https://dx.doi.org/10.1016/S0277-9536(99)00445-1

Dabla-Norris, M. E., Kochhar, M. K., Suphaphiphat, M. N., Ricka, M. F., \& Tsounta, E. (2015). Causes and consequences of income inequality: A global perspective. International Monetary Fund.

De Dominicis, L., Henri, L. F., De Groot, \& Raymond, J. G. M. F. (2006). Growth and Inequality: A Meta-Analysis (Tinbergen Institute Discussion Paper).

Deininger, K., \& Squire, L. (1998). New ways of looking at old issues: Inequality and growth. Journal of Development Economics, 57(2), 259-287. https://doi.org/10.1016/S0304-3878(98)00099-6

Delbianco, F., Dabús, C., \& Caraballo, M. Á. (2014). Income inequality and economic growth: New evidence from latin america. Cuadernos de Economía, 33(63), 381-398. https://doi.org/10.15446/cuad.econ.v33n63.45338

Dorling, D. (2010). Injustice: Why social inequality persists. Bristol: The Policy Press.

Easterly, W., Ritzen, J., \& Woolcock, M. (2006). Social cohesion, institutions, and growth. Economics \& Politics, 18(2), 103-120. https://dx.doi.org/10.1111/j.1468-0343.2006.00165.x

Forbes, K. J. (1997). A reassessment of the relationship between inequality and growth. MIT (processed).

Forbes, K. J. (2000). A reassessment of the relationship between inequality and growth. American Economic Review, 90, 869-887. https://dx.doi.org/10.1257/aer.90.4.869

Galbraith, J. K. (2012). Inequality and instability: A study of the world economy just before the great crisis (1st ed.). New York: Oxford University Press.

Galor, O., \& Moav, O. (2004). From physical to human capital accumulation: Inequality and the process of development. The Review of Economic Studies, 71(4), 1001-1026. https://dx.doi.org/10.1111/0034-6527.00312

Gasparini, L., \& Lustig, N. (2011). The rise and fall of income inequality in Latin America (No. 118). Documento de Trabajo. 
Geda, A., \& Shimeless, A. (2006). Openness, inequality and poverty in Africa. UN, Department of Economic and Social Affairs.

Gini, C. (1912). Variability and Mutability. Studi Economico-Giuridici dell'Universita di Cagliari, 3, $1-158$.

Go, D., Nikitin, D., Wang, X., \& Zou, H. F. (2007). Poverty and inequality in Sub-Saharan Africa: Literature survey and empirical assessment. Annals of Economics and Finance, 8(2), 251-304.

Green, A., Preston, J., \& Janmaat, J. G. (2006). Education, Equality and Social Cohesion: A comparative analysis. Basinstoke: Palgrave Macmillan.

Habimana, O. (2014). Inequality and Economic Growth in Sub-Saharan Africa. International Journal of Business Management \& Economic Research, 5(6), 100-103.

Han, C., Janmaat, J. G., Hoskins, B., \& Green, A. (2012). Perceptions of Inequalities: Implications for social cohesion. London: Centre for Learning and Life Chances in Knowledge Economies and Societies.

Heyse, A. (2006). Income distribution and economic growth in developing countries: An empirical analysis (Unpublished Master thesis).

Hicks, G. S., \& Streeten, P. (1979). Indicators of Development: The Search for a Basic Needs Yardstick. World Development, 7. https://dx.doi.org/10.1016/0305-750X(79)90093-7

Hunter, A., Martinez, W., \& Patel, U. (2016). Economic Growth \& Income Inequality: A revised cross-sectional econometric analysis of the global impact of income inequality on economic growth around the world.

Ilvento, T. (2013). Module 5: Multiple regression analysis (Online). Retrieved October 10, 2016, from http://www1.udel.edu/FREC/ilvento/BUAD820/MOD504.pdf

Iradian, G. (2005). Inequality, Poverty, and Growth: Cross-Country Evidence (International Monetary Fund Working Paper).

Jihène, S., \& Ghazi, B. (2013). The causality between income inequality and economic growth: Empirical evidence from the middle east and north Africa region. Asian Economic and Financial Review, 3(5), 668-682.

Kaldor, N. (1960). Essays on value and distribution. Glencoe, Ill., Free Press.

Kalecki, M. (1971). Selected essays on the dynamics of the capitalist economy. Cambridge [Eng.]: University Press.

Kefi, M. K., \& Zouhaier, H. (2012). Inequality and economic growth. Asian Economic and Financial Review, 2(8), 1013.

Lazear, E., \& Rosen, S. (1981). Rank-Order tournaments as optimum labor contracts. Journal of Political Economy, 89(5), 841-864. https://doi.org/10.1086/261010

Lee, H., Lee, M., \& Park, D. (2012). Growth policy and inequality in developing Asia: Lesson from Korea (ERIA Discussion Paper Series).

Leibbrandt, M., Woolard, I., McEwen, H., \& Koep, C. (2010). Employment and inequality outcomes in Published by SCHOLINK INC. 
South Africa. University of Cape Town: Southern Africa Labour and Development Research Unit.

Li, H., \& Zou, H. F. (1998). Income inequality is not harmful for growth: Theory and evidence. Review of development economics, 2(3), 318-334. https://dx.doi.org/10.1111/1467-9361.00045

Maxwell, O. O., \& Peter, E. G. (2016). Credit risk management and the performance of deposit money banks in Nigeria: An error correction analysis. Applied Economics and Finance, 3(2), 97-109.

Mbaku, J. M. (1997). Inequality in income distribution and economic development: Evidence using alternative measures of development. Journal of Economic Development, 22(2).

Morris, D. M. (1979). Measuring the condition of the world's poor: The physical quality of life index. New York: Pergamon Press.

Mueller, E. N. (1997). Economic determinants of democracy. In M. I. Midlarski (Ed.), Inequality, Democracy and Economic Development (pp. 133-155). Cambridge: Cambridge University Press.

Ncube, M., Anyanwu, J. C., \& Hausken, K. (2014). Inequality, economic growth and poverty in the Middle East and North Africa (MENA). African Development Review, 26(3), 435-453. https://doi.org/10.1111/1467-8268.12103

Perotti, R. (1996). Growth, income distribution, and democracy: What the data say. Journal of Economic Growth, 1, 149-187. https://doi.org/10.1007/BF00138861

Persson, T., \& Tabellini, G. (1994). Is inequality harmful for growth? The American Economic Review, 600-621.

Petrakos, G. (2009). Regional growth and inequalities in the European Union. Discussion Papers Series, 15(2), 23-44.

Pineda, J., \& Rodríguez, F. (1999). The political economy of human capital accumulation, Mimeo, Department of Economics, University of Maryland.

Ramos, R., \& Royuela, V. (2014). Income inequality in Europe. Analysis of recent trends at the regional level (No. 201425). University of Barcelona, Research Institute of Applied Economics.

Rodriguez, F. (2000). Inequality, economic growth and economic performance. A Background Note for the World Development Report.

Tabassum, A., \& Majeed, M. T. (2008). Economic growth and income inequality relationship: Role of credit market imperfection. Pakistan Development Review, 47(4), 727-743.

Wahiba, N. F., \& El Weriemmi, M. (2014). The relationship between economic growth and income inequality. International Journal of Economics and Financial Issues, 4(1), 135-143.

Wilkinson, R., \& Pickett, K. (2010). The spirit level: Why more equal societies almost always do better. London: Penguin Books. 